\title{
Determination of turgor pressure in Bacillus subtilis: a possible role for $\mathrm{K}^{+}$ in turgor regulation
}

\author{
AdRian M. WhatMore* $†$ and Robert H. ReED $\ddagger$ \\ Department of Biological Sciences, University of Dundee, Dundee DD1 4HN, UK
}

(Received 24 April 1990; revised 29 July 1990; accepted 3 September 1990)

\begin{abstract}
The effects of hypersaline treatment (osmotic upshock) on cell water relations were examined in the Gram-positive bacterium Bacillus subtilis using particle size analysis. Application of the Boyle-van't Hoff relationship (cell volume versus reciprocal of external osmolality) permitted direct determination of turgor pressure, which was approximately $0.75 \mathrm{osmol} \mathrm{kg}^{-1}(1.9 \mathrm{MPa})$ in exponentially growing bacteria in a defined medium. The abolition of turgor pressure immediately after upshock and the subsequent recovery of turgor were investigated. Recovery of turgor was $\mathrm{K}^{+}$dependent. Calculation of turgor by an alternative method involving spectrophotometric analysis of shrinkage gave somewhat lower estimates of turgor pressure.
\end{abstract}

\section{Introduction}

A cell must maintain a positive turgor pressure as the driving force for expansion growth (Taiz, 1984). Analysis of the growth of plant cells (Lockhart, 1965a,b) led to an equation expressing volumetric growth rate in terms of turgor pressure. Assuming that cell expansion occurs primarily by elongation, the equation for the rate of wall yielding is

$$
(1 / V) \Delta V / \Delta t=g\left(P-P_{\mathrm{c}}\right)
$$

where $t=$ time, $V=$ cell volume, $g=$ gross extensibility coefficient (a measure of irreversible plastic change), $\boldsymbol{P}_{\mathrm{c}}=$ critical turgor pressure (i.e. the minimum required for cell expansion) and $P=$ cell turgor pressure.

Hence this equation shows the dependence of growth rate on turgor pressure and illustrates that the mechanisms that regulate osmotic balance are fundamental to cell growth.

There have been few satisfactory measurements of turgor in bacteria. The first direct measurements of turgor in prokaryotes were made by utilizing intracellular gas vesicles. These are proteinaceous structures, which are hollow and impermeable to liquid while being permeable to gas (Walsby, 1980) and are found in a number of organisms including cyanobacteria (Walsby,

† Present address: Department of Microbiology, New Medical School, University of Newcastle, Newcastle upon Tyne NE2 4HH, UK.

¥ Present address: Department of Chemical and Life Sciences, Newcastle Polytechnic, Newcastle upon Tyne NE1 8ST, UK.

Abbreviations: OV, osmotic volume; NOV, non-osmotic volume: RI, refractive index.
1980), halophilic archaeobacteria (Walsby, 1986) and some eubacteria (Koch \& Suzanne-Pinette, 1987). Since these structures are collapsed on application of pressure, leading to a decrease in light scattering ability (Walsby, 1971), measurement of turbidity change using a pressure nephelometer can be employed to measure turgor by comparing the difference between the applied pressure required to collapse $50 \%$ of the vesicles in cells suspended in growth medium and that for cells whose turgor has been abolished by suspension in high osmolality medium.

The turgor pressure of bacteria has been estimated indirectly from the osmotic pressure of crude cell extracts (Mitchell \& Moyle, 1956) or by vapour phase equilibrium methods (Stock et al., 1977) but both methods are subject to potentially serious errors. Cyanobacterial studies (e.g. Reed et al., 1986) have utilized changes in cell volume over a range of external solute concentrations to calculate turgor. Above a threshold solute level turgor will be abolished and cells should act as ideal osmometers in accordance with the Boyle-van't Hoff relationship. Hence turgor can be calculated by comparing the osmotic volume of cells where turgor is eliminated with that of cells in their orginal medium.

Since Bacillus subtilis lacks gas vesicles, in common with other Gram-positive eubacteria, this latter method was used to obtain the first measurements of turgor in viable cells of Gram-positive bacteria. As $\mathrm{K}^{+}$accumulation is known to be the primary response to osmotic upshock in a number of micro-organisms (Epstein, 1986; Csonka, 1989) the influence of this ion on turgor recovery after upshock was also examined. 


\section{Methods}

Organism, media and growth conditions. Bacillus subtillis NCIB 1650 was obtained from the National Collection of Industrial Bacteria, Aberdeen, UK. Preliminary experiments were done in nutrient broth (Oxoid no. 2), but for later work a defined glucose mineral salts medium with the following composition ( $\mathrm{g}^{-1}$ except for buffer) was used: $100 \mathrm{~mm}$-sodium phosphate buffer, $\mathrm{pH} 7.0 ;\left(\mathrm{NH}_{4}\right)_{2} \mathrm{SO}_{4}, 2.0$; $\mathrm{MgSO}_{4} .7 \mathrm{H}_{2} \mathrm{O}, 0.2 ;$ glucose, $5.0 ; \mathrm{KCl}, 0.37 ; \mathrm{Na}_{3} \mathrm{C}_{6} \mathrm{H}_{5} \mathrm{O}_{7} .2 \mathrm{H}_{2} \mathrm{O}$ (sodium citrate), $1.0 ; \mathrm{FeSO}_{4} .7 \mathrm{H}_{2} \mathrm{O}, 0.0025 ; \mathrm{ZnSO}_{4} .7 \mathrm{H}_{2} \mathrm{O}, 0.0025$; $\mathrm{MnSO}_{4} \cdot 3 \mathrm{H}_{2} \mathrm{O}, 0.0025$. Identical medium without $\mathrm{KCl}$ was used in studies of the effects of $\mathrm{K}^{+}$starvation on turgor pressure. All experiments were done at $25^{\circ} \mathrm{C}$.

Determination of cell volume and number. Cells were counted and sized using a Coulter counter (ZBI) and $\mathrm{C} 1000$ Channelyzer linked to an Acorn microcomputer to facilitate rapid estimates of mean cell volume and biovolume density (BVD - the total cellular volume per $\mathrm{ml}$ of culture). A $30 \mu \mathrm{m}$ aperture with path length $60 \mu \mathrm{m}$ was used throughout. To prevent volume changes during analysis cells were counted and sized in an isotonic salt solution and the osmolality was the same on both sides of the aperture tube. For each volume determination three to six replicates were used with $15000-25000$ cells per sample.

Calculation of turgor pressure $(P)$ and non-osmotic volume (NOV). These values were obtained by application of the Boyle-van't Hoff relationship. Cells were suspended in filtered (Millipore, $0.22 \mu \mathrm{m}$ ) salt solutions with osmolalities ranging from that of the growth medium (nutrient broth $=0.271 \mathrm{osmol} \mathrm{kg}$; defined medium $=0.290 \mathrm{osmol}$ $\mathrm{kg}^{-1}$ ) to $8.672 \mathrm{osmol} \mathrm{kg}^{-1}$. The osmolalities of these solutions were confirmed using a cryoscopic osmometer (Gonotec, Osmomat 030). After suspension in a salt solution, samples were allowed to stand for $60 \mathrm{~s}$ to allow osmotically induced volume changes to occur and then their volumes were measured using the Coulter counter. The cell volume was then plotted against the reciprocal of the external osmolality and these Boyle-van't Hoff plots were then used to determine a number of osmotic parameters, including cell osmotic pressure $\left(\pi_{\text {cell }}\right)$.

On transfer to a hyperosmotic solution water will flow from the cell leading to a reduction in turgor. Cell volume $\left(V_{\text {cell }}\right)$ will also change in accordance with the following relationship

$$
P_{\text {cell }}=\varepsilon\left(\Delta V_{\text {cell }} / V_{\text {cell }}\right)
$$

where $\varepsilon=$ volumetric elastic modulus (Dainty, 1976). If external osmolality $\left(\pi_{\text {ext }}\right)$ is raised sufficiently, turgor will be abolished. At all values above this point the cell behaves as a perfect osmometer $\left(\pi_{\text {cell }}=\pi_{\text {ext }}\right)$ shrinking in a manner directly proportional to the reciprocal of the external osmolality, in accordance with the Boylevan't Hoff relationship.

Hence $\left(V_{\text {cell }}-b\right) \propto 1 /$ external osmolality where $b=$ non-osmotic volume (NOV). The intercept of the ordinate of the plot of $V_{\text {cell }}$ against $1 /$ external osmolality gives $b$, the NOV, from which osmotic volume can be determined $\left(V_{\text {cell }}-b\right)$. Hence for any osmolality where $P=0$, turgor can be calculated by comparing the osmotic volume of cells in their orginal medium with the osmotic volume where turgor is abolished since $P=\pi_{\text {cell }}-\pi_{\text {ext }}$.

Turgor recovery after osmotic upshock. Turgor pressure was determined at intervals after osmotic upshock of mid-exponential phase cells by preparation of Boyle-van't Hoff plots as described above. Cells were diluted in medium containing sufficient salt to give a final concentration of $400 \mathrm{~mm}$ and this point was taken as time 0 (each plot took about $30 \mathrm{~min}$ to complete). Boyle-van't Hoff plots were prepared at 0,2 and $5 \mathrm{~h}$. Recovery of turgor under $\mathrm{K}^{+}$-free conditions was examined by harvesting cells by centrifugation and then washing them twice in defined medium devoid of $\mathrm{KCl}$. The cells were then resuspended in $\mathrm{K}^{+}$-free medium with $400 \mathrm{M}-\mathrm{NaCl}$ and Boyle-van't Hoff plots prepared as previously.

Calculation of turgor and associated parameters by spectrophotometric analysis of shrinkage. Since the shrinkage of cells leads to a corresponding increase in optical density, osmotic parameters were determined using a spectrophotometric method. Koch (1984) has shown that rod-shaped bacteria have an optical density proportional to the inverse of their surface area. The optical density, corrected for effects of alteration of the index of refraction, increases as external osmolality rises, due to cell shrinkage. Thus the theoretical relationship proposed by Koch (1984) can be used to quantify the relative change in volume (in arbitrary units) of the cells.

Ficoll, a high molecular mass polymer of sucrose, was used to correct for refractive index changes at constant external osmolality since it alters refractive index (RI) but, because of its size, has no appreciable osmotic effect. Standard Ficoll solutions were prepared and their RI measured on a bench refractometer. The effect of RI on optical density was then determined by centrifuging exponentially growing $B$. subtilis and resuspending in a mimimal volume of growth medium to give a highly concentrated cell suspension. A small volume $(25 \mu 1)$ of this suspension was then mixed with $1 \mathrm{ml}$ of a Ficoll solution of known refractive index and the $\mathrm{OD}_{660}$ measured on a Pye Unicam SP1800 spectrophotometer. A standard curve was obtained from which a correction factor for the effect of $\mathrm{RI}$ on $\mathrm{OD}_{660}$ of $B$. subtilis in increasingly concentrated salt solutions could be determined (the RI of salt solutions was obtained from standard tables).

Boyle-van't Hoff plots were prepared by measuring the $\mathrm{OD}_{660}$ of $B$. subtilis suspended in a range of salt solutions $\left(0 \cdot 290-8 \cdot 672 \mathrm{osmol} \mathrm{kg}^{-1}\right)$ and correcting for the change in refractive index of each salt solution. The reciprocal of these corrected values is proportional to the surface area (Koch, 1984). From this reciprocal value the cell volume was determined as the $3 / 2$ power of the surface area (in arbitrary units). Boyle-van't Hoff plots were then prepared by plotting the cell volume as a percentage of the orginal volume (in salt solution isotonic with the growth medium) against the reciprocal of the external osmolality (Whatmore, 1989).

\section{Results}

Boyle-van't Hoff plots consistently showed that, below a certain threshold, $B$. subtilis cells behaved as ideal osmometers, with a linear relationship between cell volume and the reciprocal of the external osmolality. The Boyle-van't Hoff plots could be used to derive the NOV and cell turgor pressure $(P)$ at any given external osmolality. Calculation of the internal osmolality depends on the relationship $P_{\text {cell }}=\pi_{\text {int }}-\pi_{\text {ext }}$. At high $\pi_{\mathrm{ext}}$, when $P_{\text {cell }}=0, \pi_{\mathrm{ext}}=\pi_{\mathrm{int}}$. Thus having calculated a value for $\pi_{\text {int }}$, at a volume where $P_{\text {cell }}=0$, the Boyle-van't Hoff relationship can be applied ( $\pi V=$ constant) to calculate $\pi_{\text {int }}$ where $P$ is positive.

Taking Fig. 1 as an example, the initial volume in a salt solution isotonic with the growth medium was $1.18 \mu \mathrm{m}^{3}$ and the NOV can be determined from the intercept of the ordinate as $0.47 \mu \mathrm{m}^{3}$. From this value the osmotic volume $(\mathrm{OV})$ can be calculated $(\mathrm{OV}=$ total $V-\mathrm{NOV}$ ) as $0.71 \mu \mathrm{m}^{3}$. 


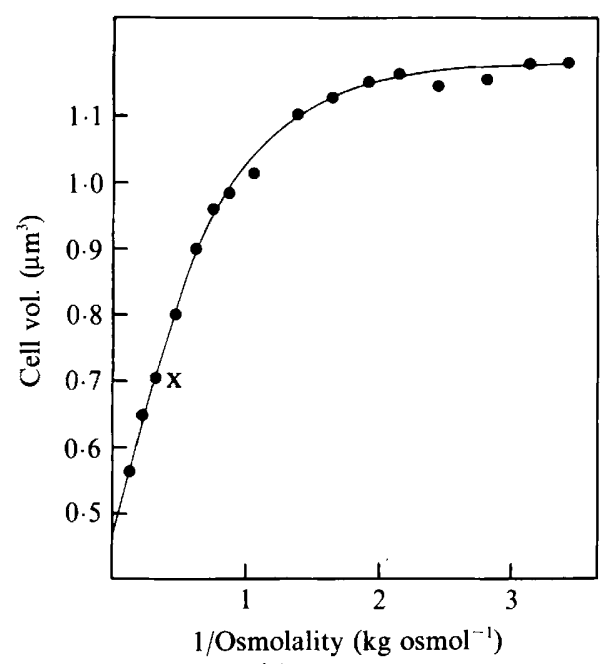

Fig. 1. Boyle-van't Hoff plot - changes in cell volume of $B$. subtilis with the reciprocal of the external osmolality. Exponentially growing cells in defined medium. Mean of four to six replicates. $P=\mathbf{0 . 7 5 3} \mathrm{osmol} \mathrm{kg}^{-1}$; $\mathrm{NOV}=39.8 \% . \mathrm{X}$ indicates the point used to calculate turgor, where $P_{\text {cell }}=0$ (see text).

The OV of the cell at any point where $P_{\text {cell }}=0$ is then calculated (marked $X$ on Fig. 1), i.e. $0 \cdot 70-0.47=$ $0.23 \mu \mathrm{m}^{3}$. The Boyle-van't Hoff relationship can then be applied as follows

$$
V_{\mathrm{x}} \cdot \mathrm{Osm}_{\mathrm{x}}=V_{\text {original }} \cdot \mathrm{Osm}_{\text {original }}
$$

where $V_{\mathrm{x}}=$ osmotic volume when $P_{\text {cell }}=0, \mathrm{Osm}_{\mathrm{x}}=$ internal osmolality when $P_{\text {cell }}=0, V_{\text {original }}=$ osmotic volume in the original medium and Osm $_{\text {original }}=$ internal osmolality in the original medium.

Hence $0.23 \times 3.22=0.71 \times$ Osm.

Therefore Osm $_{\text {original }}=1.043 \mathrm{osmol} \mathrm{kg}^{-1}$.

And since $P=\mathrm{Osm}_{\mathrm{int}}-\mathrm{Osm}_{\mathrm{ext}}, \quad P=1.043-0.290=$ 0.753 osmol kg-1

Values obtained for turgor pressure varied somewhat between batches although results obtained from duplicate plots from the same cell batch were reproducible. Values of $P$ for exponentially growing cells in nutrient broth ranged from $0.556-0.935$ osmol $\mathrm{kg}^{-1}$ with a mean

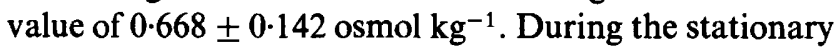
phase turgor pressure was somewhat lower at $0.527 \pm$ 0.021 osmol kg-1.

In exponential phase cells NOV was generally $25-35 \%$ rising to $45-55 \%$ in the stationary phase. NOV values in subsequent experiments using a defined medium were generally higher. The change to defined medium was necessary to examine the role of $\mathrm{K}^{+}$in osmotic recovery and to enable further studies linking the accumulation of organic solutes to turgor recovery (accompanying paper: Whatmore et al., 1990) to be made. Fig. 1 shows a typical Boyle-van't Hoff plot obtained in minimal medium with $P=0.753$ osmol kg-1.

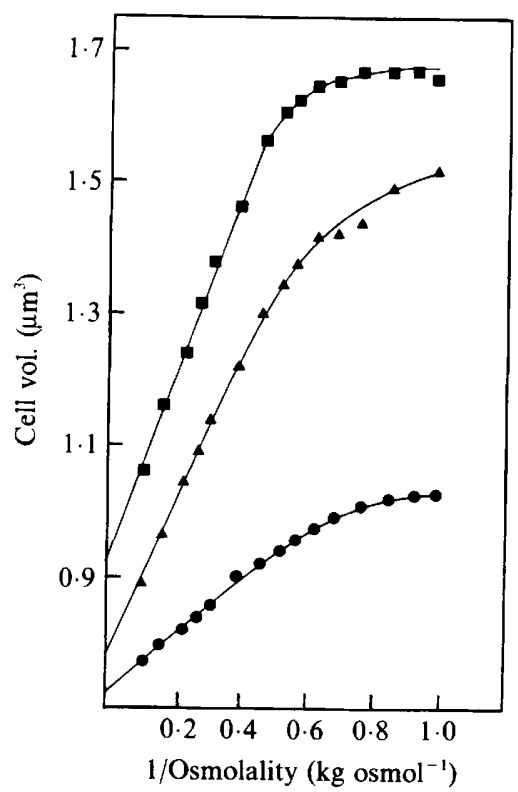

Fig. 2. Boyle-van't Hoff plots - changes in cell volume of $B$. subtilis with the reciprocal of the external osmolality after upshock with $400 \mathrm{~mm}-\mathrm{NaCl}$. Mean of four to six replicates. Time after upshock (h): 0,$0 ; \Delta, 2 ; \square, 5$. Each curve took approximately $30-45 \mathrm{~min}$ to complete and data were corrected where necessary for volume change due to growth over this period. $O, P=0.325$ osmol $\mathrm{kg}^{-1}$, $\mathrm{NOV}=70.9 \% ; \Delta, P=0.489 \mathrm{osmol} \mathrm{kg}{ }^{-1}, \mathrm{NOV}=52.0 \% ; \boldsymbol{\square}, P=0.757$ osmol kg-1, NOV $=55.4 \%$.

Table 1. Effect of osmotic upshock and $K^{+}$depletion on turgor

\begin{tabular}{lcc}
\hline \hline & $P($ osmol kg-1) & NOV (\%) \\
\hline No upshock & 0.753 & 39.8 \\
Upshocked $(+\mathrm{KCl})$ & & \\
$0 \mathrm{~h}$ & 0.325 & 70.9 \\
$2 \mathrm{~h}$ & 0.489 & 52.0 \\
$5 \mathrm{~h}$ & 0.757 & 55.4 \\
Upshocked $(-\mathrm{KCl})$ & & \\
0 h & 0.328 & 69.8 \\
$2 \mathrm{~h}$ & 0.000 & - \\
No upshock $(-\mathrm{KCl})$ & & \\
$0 \mathrm{~h}$ & 0.444 & 55.4 \\
$2 \mathrm{~h}$ & 0.484 & 56.4 \\
$5 \mathrm{~h}$ & 0.377 & 64.2 \\
\hline \hline
\end{tabular}

Data illustrated in Fig. 2 and summarized in Table 1 show the recovery of turgor pressure in cells upshocked in defined medium from $0-400 \mathrm{~mm} \mathrm{NaCl}$. It can be seen that initially $(0 \mathrm{~h})$ turgor was substantially reduced from the value in control cells of $0.753 \mathrm{osmol} \mathrm{kg}^{-1}$ (Fig. 1) to 0.325 osmol kg-1. Over the subsequent $5 \mathrm{~h}$ period turgor pressure recovered to the pre-shock value. Growth (cell division) of the cultures generally resumed some $4 \mathrm{~h}$ after upshock (Whatmore, 1989). 


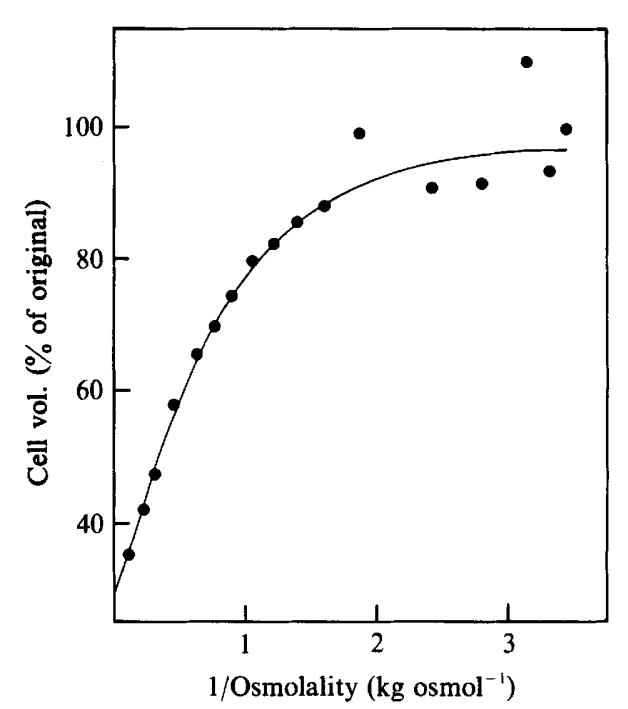

Fig. 3. Boyle-van't Hoff plot - changes in cell volume of $B$. subtilis with the reciprocal of the external osmolality. Data obtained by the spectrophotometric analysis of shrinkage. Mean of three replicates. $P=0.649$ osmol kg-1, NOV $=28.9 \%$.

The data summarized in Table 1 demonstrate that $\mathrm{K}^{+}$ is essential for the recovery of the turgor in this organism. After upshock in $\mathrm{K}^{+}$-free medium with $400 \mathrm{mM}-\mathrm{NaCl}$, turgor fell in a manner similar to that seen in $\mathrm{K}^{+}$-replete medium. However, no recovery of turgor was apparent with time - indeed, after $2 \mathrm{~h}$ turgor had been totally dissipated and the Boyle-van't Hoff shouldered curve was reduced to a straight line, typical of that for a (nonturgid) cell, showing osmometric behaviour.

B. subtilis could maintain turgor in the absence of $\mathrm{K}^{+}$ when not subjected to osmotic upshock (Table 1). The values of $P$ obtained were somewhat lower than those obtained previously in $\mathrm{K}^{+}$-replete medium, possibly as a consequence of the washing procedures used to remove external $\mathrm{K}^{+}$, but the key feature was illustrated clearly. Thus turgor, after rinsing, was $0.444 \mathrm{osmol} \mathrm{kg}^{-1}$ and, in contrast to the data shown for loss of turgor after salt shock in the absence of $\mathrm{K}^{+}$, there was no further loss of turgor after $2 \mathrm{~h}$ incubation with $P$ at 0.484 osmol kg-1. Indeed after $6 \mathrm{~h}$ incubation, turgor had dropped by only $24 \%$ to 0.337 osmol $\mathrm{kg}^{-1}$.

Fig. 3 shows a typical Boyle-van't Hoff plot prepared by spectrophotometric analysis of shrinkage. Refractive index, independent of external osmolality, was found to have a considerable influence on the $\mathrm{OD}_{660}$, but the effect was linear over the range of RI of the salt concentrations used to prepare Boyle-van't Hoff plots, so a correction factor could readily be obtained. Measured $\mathrm{OD}_{660}$ over the range of salt solutions used varied in this example (Fig. 3) only from $0 \cdot 385-0 \cdot 515$. However, correction for RI increased this range to $0 \cdot 385-0.776$.
Turgor pressures calculated by this method were slightly lower than those determined by particle size analysis, being generally in the range $0.5-0.65$ osmol $\mathrm{kg}^{-1}$. In addition, the NOV was somewhat lower at around $30 \%$.

\section{Discussion}

The results presented in this paper represent the first measurements of turgor in viable cells of a Grampositive bacterium. Due to the technical difficulties involved there have been few estimates of osmotic parameters in bacteria. Mitchell \& Moyle (1956) were the first to show that Gram-positive bacteria maintained a much higher turgor than their Gram-negative counterparts. Plasmolysis threshold studies in Escherichia coli suggested a turgor pressure of 2-3 atm. (about $0 \cdot 1 \mathrm{osmol}$ $\mathrm{kg}^{-1}$ ). Generally, Gram-positive organisms cannot be plasmolysed so Mitchell \& Moyle (1956) developed a vapour pressure equilibrium technique and estimated the turgor pressure of Staphylococcus aureus to be 20-25 atm. (0.8-1.0 osmol kg-1). Marquis \& Carstensen (1973) estimated the internal osmolality of Streptococcus faecalis and Micrococcus lysodeikticus to be 1.0 and $0.5 \mathrm{osmol}$ $\mathrm{kg}^{-1}$ respectively. The results presented here have given comparable values for turgor pressure using greatly simplified and more direct experimental techniques, without the need for cell disruption.

There have been few other estimates of turgor in eubacteria though Koch \& Suzanne-Pinette (1987) have exploited the gas vesicles of the Gram-negative heterotroph Ancylobacter aquaticus and calculated turgor at $0.187 \mathrm{MPa}(0.08$ osmol kg-1), a value not dissimilar to estimates of turgor in $E$. coli obtained from earlier turbidometric studies (Koch, 1984). There are several estimates of turgor for aquatic eukaryotic phototrophic micro-organisms: they vary widely from species to species though most are considerably lower than values presented for Gram-positive bacteria (Cram, 1976). Recent estimates of turgor for the eukaryotic heterotroph Saccharomyces cerevisiae (Meikle et al., 1988) gave a value of $0.81 \mathrm{MPa}\left(0.33 \mathrm{osmol} \mathrm{kg} \mathrm{kg}^{-1}\right)$ for exponential phase cells. Turgor was reduced somewhat in stationary phase $S$. cerevisiae $(0.61 \mathrm{MPa})$ as it was in $B$. subtilis. A decrease in turgor pressure in the stationary phase is to be expected since the cells no longer require a critical turgor pressure for growth.

$B$. subtilis appeared to behave as an ideal osmometer, once turgor had been abolished, showing a linear relationship between the cell volume and the reciprocal of the external osmolality, in accordance with the Boylevan't Hoff relationship. Plots prepared using sucrose, rather than $\mathrm{NaCl}$, over the range $0-1.0$ osmol $\mathrm{kg}^{-1}$ 
(higher concentrations could not be used due to viscosity and solubility restrictions) were virtually identical (data not shown). However some cyanobacteria, such as Synechococcus sp., show dissimilar responses to different solutes, due to the solutes crossing the cell membrane to varying degrees and hence invalidating use of the Boylevan't Hoff relationship to estimate turgor pressure (Reed et al., 1986).

Determination of turgor pressure via the method of spectrophotometric analysis produced similar Boylevan't Hoff plots to the particle size analysis procedure. However, spectrophotometric estimates of turgor obtained were somewhat lower than those obtained using the particle size analyser. While the spectrophotometric method gave reasonable results it should be noted that in reality the measured differences in $\mathrm{OD}_{660}$ were fairly small, with the correction factor being responsible for much of the change. Both this factor, and the reliance on theoretical mathematical concepts, suggest that the more direct method using the particle size analyser should be the more appropriate method.

It is clear that the NOV was a considerable proportion of the cell volume under all conditions. This has been shown for a variety of organisms: in algae the NOV ranges from $20 \%$ to as high as $80 \%$ (Wyn-Jones \& Gorham, 1983), while in $S$. cerevisiae it is about $48 \%$ (Meikle et al., 1988). The nature of the NOV is unclear, but it may include cellular organelles, storage components and cell wall material. In $B$. subtilis the NOV increased considerably in the stationary phase, possibly as a result of an increased proportion of storage components or other compounds accumulated in preparation for sporulation and/or a thicker cell wall as a result of reduced rates of cell division at the end of the growth phase.

Data presented in Fig. 2 and Table 1 show that $B$. subtilis transferred to hypersaline medium recovered turgor completely, at least at this level of upshock $(400 \mathrm{~mm}-\mathrm{NaCl})$. The combined data shown in Table 1 imply that $\mathrm{K}^{+}$play an active role in the recovery of turgor pressure. $\mathrm{K}^{+}$, present in the medium, were required in order to regain turgor pressure. Indeed, even the reduced turgor after upshock could not be maintained in the absence of $\mathrm{K}^{+}$, though the cells were capable of maintaining turgor in the absence of $\mathrm{K}^{+}$if they were not subjected to osmotic upshock. A role for $\mathrm{K}^{+}$in turgor recovery has previously been postulated in a variety of organisms (Epstein, 1986; Csonka, 1989); a turgorsensitive $\mathrm{K}^{+}$influx system is thought to be involved in short-term turgor recovery in Synechocystis PCC 6714 (Reed \& Stewart, 1985) and Microcystis sp. (Reed \& Walsby, 1985). It is also clear that $\mathrm{K}^{+}$uptake is the primary initial response to osmotic upshock in Gramnegative eubacteria (Epstein, 1986; Higgins et al., 1987), and may serve as the signal for accumulation of more metabolism-compatible organic solutes in order to restore osmotic balance.

We suggest that the primary response to osmotic upshock in $B$. subtilis is accumulation of $\mathrm{K}^{+}$via a turgorsensitive transport system. An examination of this accumulation and its possible role in the accumulation of other organic solutes is contained in the following paper (Whatmore et al., 1990).

This work was supported by a SERC studentship to A.M.W.

\section{References}

CRAM, W. J. (1976). Negative feedback regulation of transport in cells. The maintenance of turgor, volume and nutrient supply. In Encyclopedia of Plant Physiology, New Series, vol. 2A, pp. 284-316. Edited by U. Lüttge \& M. G. Pitman. Berlin: Springer-Verlag.

CsONKA, L. N. (1989). Physiological and genetic responses of bacteria to osmotic stress. Microbiological Reviews 53, 121-147.

DAINTY, J. (1976). Water relations of plant cells. In Encyclopedia of Plant Physiology, New Series, vol. 2A, pp. 12-35. Edited by U. Lüttge.\& M. G. Pitman. Berlin: Springer-Verlag.

EPSTEIN, W. (1986). Osmoregulation by potassium transport in Escherichia coli. FEMS Microbiology Reviews 39, 73-78.

Higgins, C. F., Cairney, J., Stirling, J. A., Sutherland, L. \& BoOTH, I. R. (1987). Osmotic regulation of gene expression: ionic strength as an intracellular signal? Trends in Biochemical Sciences 12, 339-344.

KoCH, A. L. (1984). Shrinkage of growing cells of Escherichia coli by osmotic challenge. Journal of Bacteriology 159, 919-924.

KOCH, A. L. \& SuZANNE-PINETTE, M. F. (1987). Nephelometric determination of turgor pressure in growing Gram-negative bacteria. Journal of Bacteriology 169, 3654-3663.

LOCKHART, J. A. (1965a). An analysis of irreversible plant cell elongation. Journal of Theoretical Biology 8, 264-273.

LOCKHART, J. A. (1965b). Cell extension. In Plant Biochemistry, pp. 827-849. Edited by J. Bonner \& J. E. Vanner. New York: Academic Press.

Marquis, T. E. \& Carstensen, E. L. (1973). Electric conductivity and internal osmolality of intact bacterial cells. Journal of Bacteriology 113, 1198-1206.

Meikle, A. J., Reed, R. H. \& GadD, G. M. (1988). Osmotic adjustment and the accumulation of organic solutes in whole cells and protoplasts of Saccharomyces cerevisiae. Journal of General Microbiology 134, 3049-3060.

Mitchell, P. \& MOYLE, J. (1956). Osmotic structure and function in bacteria. In Bacterial Anatomy, 6th Symposium of the Society for General Microbiology, pp. 150-180. Cambridge: Cambridge University Press.

ReEd, R. H. \& StewaRT, W. D. P. (1985). Evidence for turgor sensitive $\mathrm{K}^{+}$influx in the cyanobacteria Anabaena variabilis ATCC 29413 and Synechocystis PCC 6714. Biochimica et Biophysica Acta 812, 155-162.

REED, R. H. \& W ALSBY, A. E. (1985). Changes in turgor pressure in response to increase in external $\mathrm{NaCl}$ concentration in the gas vacuolate cyanobacterium Microcystis sp. Archives of Microbiology 143, 290-296.

ReEd, R. H., Richardson, D. L. \& StewaRT, W. D. P. (1986). Osmotic responses of unicellular blue-green algae (cyanobacteria): changes in cell volume and intracellular solute levels in response to hyperosmotic treatment. Plant Cell and Environment 9, 25-31.

Stock, A. R., Falkenberg, P. \& Landfald, B. (1977). Periplasmic space in Salmonella typhimurium and Escherichia coli. Journal of Biological Chemistry 252, 7850-7861.

TAIZ, L. (1984). Plant cell expansion: regulation of cell wall mechanical properties. Annual Review of Plant Physiology 35, 585-657. 
WALSBY, A. E. (1971). The pressure relationships of gas vacuoles. Proceedings of the Royal Society of London B178, 201-206.

WALsBY, A. E. (1980). The water relations of gas vacuolate prokaryotes. Proceedings of the Royal Society of London B208, 72-102.

WALSBY, A. E. (1986). The pressure relationships of halophilic and non-halophilic prokaryotic cells determined by using gas vesicles as pressure probes. FEMS Microbiology Reviews 39, 45-49.

WhATMORE, A. M. (1989). Osmotic responses of Bacillus subtilis. MSc thesis, University of Dundee, UK.
Whatmore, A. M., Chudek, J. A. \& ReEd, R. H. (1990). Effect of osmotic upshock on intracellular solute pools of Bacillus subtilis. Journal of General Microbiology 136, 2527-2535.

WYN-JONES, R. G. \& GORHAM, J. (1983). Osmoregulation. In Encyclopedia of Plant Physiology, New Series, vol. 12C, pp. 171-204. Edited by O. L. Lange, P. S. Nobel, C. S. Osmond \& H. Ziegler. Berlin: Springer-Verlag. 